\title{
People-driven urbanism: implications in the making of Indonesian urban character
}

\author{
Wiryono Raharjo ${ }^{1, *}$ \\ ${ }^{1}$ Department of Architecture, FCEP, Universitas Islam Indonesia
}

\begin{abstract}
The history of urban planning and design of contemporary Indonesian cities can be traced back to the colonial era. The colonial government, notably the Dutch, had made continuous intervention in the planning and design of major cities in today's Indonesia, which have undoubtedly influenced the character of these cities. While time between the Dutch era and today spans over three centuries, the paradigm of urban development in Indonesia seems largely unchanged. It has been characterized by the built environment that exist as a result of peopledriven development (PDD), ranging from everyday businesses to the country-wide proliferation of informal settlements weakly controlled by the state. This paper discusses how PDD have influenced the urban character of Indonesian cities, which I call 'People-Driven Urbanism' (PDU). The main question this paper intends to respond is "how does PDD affect the urban character of Indonesian cities?' Methods employed in this research is a mix of case study and auto-ethnography. The case study looks particularly on the city of Yogyakarta, using data collected from previous teaching assignments on Architectural Design Studio and Informal Urbanism. Keywords: people-driven development, informal urbanism, urban character, place identity.
\end{abstract}

\section{Introduction}

Within the discourse of urban development, the term "Community-Driven Development" (CDD) has been defined by The World Bank as an approach of development through which a community group plays a central role in the decision-making process. CDD projects are mainly conducted in response the need of communities to improve their living quality [1]. Most references on CDD often see CDD as a strategy for poverty reduction. A good example is the Indonesia's PNPM - Program Nasional Pemberdayaan Masyarakat National Programs on Community Empowerment [3]. I suggest this type of CDD may be called "State Engineered CDD", because it occurs through a systematic preparation by the state as part of their development policies. Other type of CDD, which I call "Indigenous CDD", is a type of CDD purely initiated by the people without government's intervention.

While PDD denotes the same meaning with that of CDD, PDD includes not only collective but also individual contribution to the shaping of the built environment. An

* Corresponding author: raharjo@uii.ac.id 
example of the case is the street hawkers in Yogyakarta, which become massive because of gradual encroachment by one hawker followed by others. Therefore, the term PDD is chosen to represent the subject of this paper. PDD consists of broad-range of developments, from street hawkers encroaching the pedestrian ways to informal settlements developing along the riverbank, as well as formalization of these informal settlements. Moreover, PDD operates not only within the area of urban informality. Market-driven property development is an example of PDD on housing supply that often shapes the direction of urban growth in Indonesia, which in some cities - including Yogyakarta - have caused the mismatch between urban planning and design due to the weak control of authority.

So how can we define people-driven urbanism (PDU)? In dictionary term, urbanism is defined as "the character of life in cities" [1]. The definition implies that urbanism is naturally people-driven, which may make the title of this paper look redundant. However, I want to reframe and highlight the notion of people-driven to make it different from the notion of state-driven. People-driven is the process of development dominantly controlled by people, while state-driven relies on the central role of the state in taking the control. Ideally, state-driven development is a form of development that should be fully operated in the city because the state is responsible for making the city in a good order.

This paper examines the role of PDD in shaping the urban character of Yogyakarta. It intends to respond to what extent does PDD affect the urban character of Yogyakarta? Can such character be seen as an expression of place identity?

\section{Methods of research}

This research employs case study method, using the city of Yogyakarta as the locus of observation. Case study is an empirical investigation of certain contemporary phenomenon within its real-life context [4]. The research focuses the area of investigation only on the changing of the built environment as a result of PDD. Longitudinal approach is employed to identify its continuity and change. Longitudinal approach is the "research emphasizing the study of change and containing at minimum three repeated observations (although more than three is better) on at least one of the substantive constructs of interest" [5].

The range of time varies from one to other observed areas depending upon the availability of information about the observed area. Autoethnography approach [6] is employed as well through the writing of my past observation on the targeted area, including data obtained from my teaching activities in the past. The observed settlements consist of two areas: one represents a predominantly informal settlement while other represents the predominantly formal settlement. The former is informal settlements along the Code (pronounced "Cho-de") riverbank while the latter is the settlements along Jalan Kaliurang (Kaliurang Street), which started to grow fast in the 1990s and continues today.

\section{Review of related literatures}

\subsection{People-driven urbanism}

In 1976, Turner published a seminal work titled "Housing by People", which saw the importance to put the involvement of people in the decision-making related to the design of housing [7]. Over the years their work has inspired many countries to develop the so called "Enabling strategies" to overcome the need of housing particularly for the poor and the homeless. It became a foundation for developing housing strategy endorsed by UN -Habitat [8]. However, Turner certainly was not the one who invent such approach. He learned from the practice of local people in Peru [7], which has actually been existed in the indigenous 
communities in many places in the world. In Indonesia we have been practicing "gotong royong" (mutual cooperation) for generations. Mutual cooperation is an informal way of helping each other in any circumstances, including neighborhood maintenance and improvement. The basic platform of this approach is dweller's control over the process of development.

In the countries where supports to infrastructure and housing development are lacking, the above mutual cooperation approach becomes the main strategy for survival, which often led to development of informal settlements. Barrios in Venezuela, favelas in Brazil, and kampung in Indonesia are all the outcomes of such survival strategies, which have been frequently studied $[9,10,11,12]$. This paper argues that the notion of 'informal' is not the same as 'illegal' because state recognition often occurs within the informal development. A common example in Indonesia is the legal connection of electricity and water supplies in a settlement that exists on unauthorized land. Another example is slum upgrading program that occurs as a part of pro- poor housing strategies in many developing countries including Indonesia. This program often ignores land tenure issue because the main objective is to improve the physical conditions of the built environment. Indonesia has, in the past, implemented the award-winning KIP (Kampung Improvement Programs), which can be seen as similar to the current practice of KOTAKU (Kota Tanpa Kumuh - City Without Slum). Guinness sees the practice of state intervention to upgrade the condition of informal settlements as a form of "formalization" [13]. Therefore, I suggest that formalization is not the same as legalization. This paper sees that formalization in the form of state intervention is an important stage for the residents of informal settlements to be recognized by the state, a part of tenure stabilization process that leads to the gaining of informal secure tenure (Fig. $1)$.
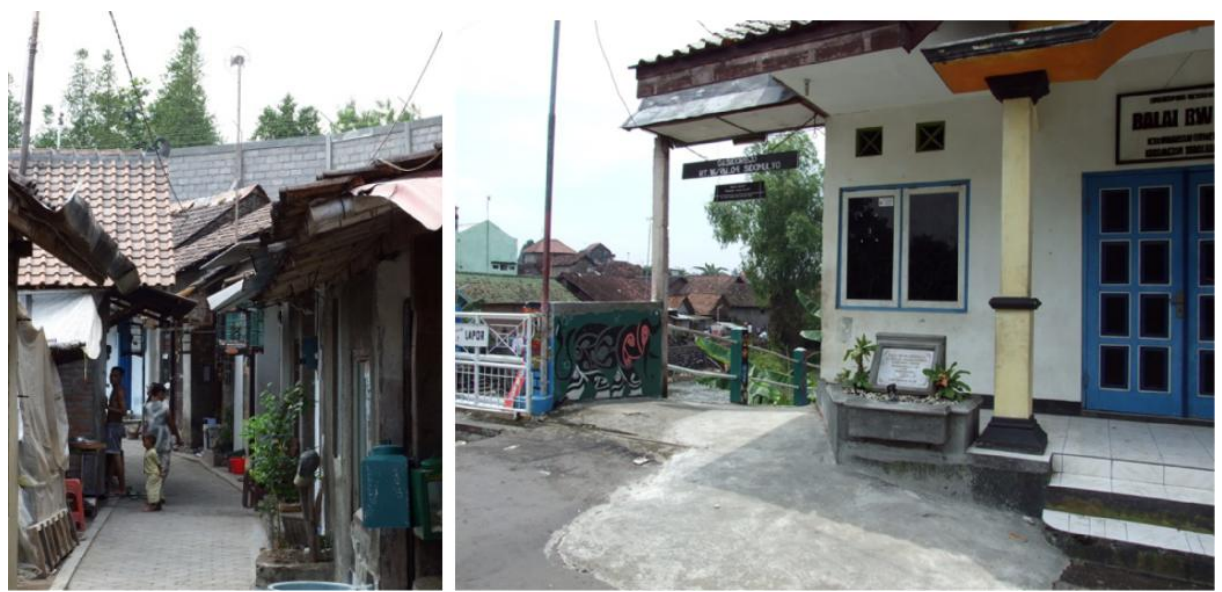

Fig. 1. [Left] State intervention in the form of paved lane and electricity supply in an informal settlement on the bank of Winongo River, Yogyakarta; [Right] A tablet installed in front of a community hall signed by Mayoral Candidate of Yogyakarta, to inaugurate the opening of the hall. The hall was built within the area of such informal settlement (Photographed by author in 2008)

The above discussion explains how people-driven development (PDD) has influenced the way human settlements developed. Referring to the notion of PDD discussed in Section 1, people-driven urbanism can then be defined as urbanism that operates as a result of people's initiatives, which can be a result of both individual and collective efforts, either formal or informal. I will further discuss this in Section 4. 


\subsection{Urban character and place identity}

Dovey describes the neighborhood character as "the 'feel' or 'atmosphere' of a neighborhood" [14]. Urban character is thus the 'feel' or atmosphere of certain urban area, which according to Kropf "is dependent upon both the observer and the observed" [15:249]. Kropf further states that (urban) character is about differences [15]. Urban character can then be identified by looking at differences of one city from others. However, I suggest the differences can also be identified by observing the built environment of the same area at several different times, which is the intention of this paper. With regard to the notion of identity, Martin Heidegger argues that "Identity is belonging-together. If the element of together in belonging-together is emphasized, we have the metaphysical concept of identity which orders the manifold into a unity mediated by synthesis" [16]. In this paper, the synthesis is the difference of the present state of urban character from the past one, which is the basis for identifying the existence of place identity.

\section{Result and discussion}

As described earlier, this paper examines two case studies. The first one represents predominantly formal built environment, i.e., a mix of residential and commercial buildings along Jalan Kaliurang (Kaliurang Road). The second represents a predominantly informal built environment - an informal settlement located along the Code River in the city of Yogyakarta. The following subsections discuss each case study:

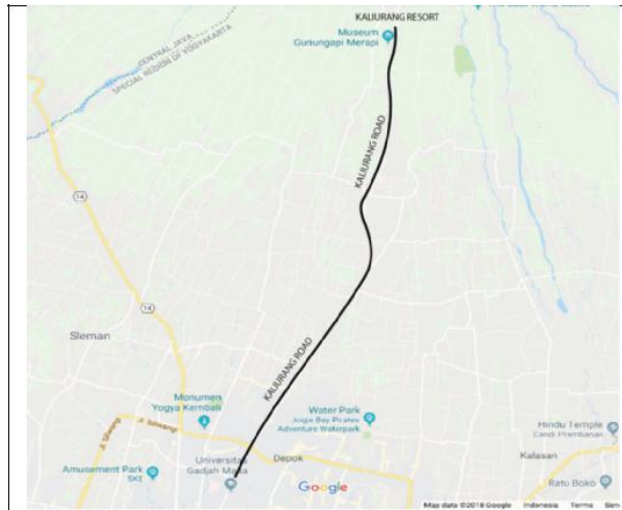

Fig. 2. [Top] Jalan Kaliurang links Yogyakarta city and Kaliurang Resort; [Right] Jalan Kaliurang was called Pakemweg in 1925

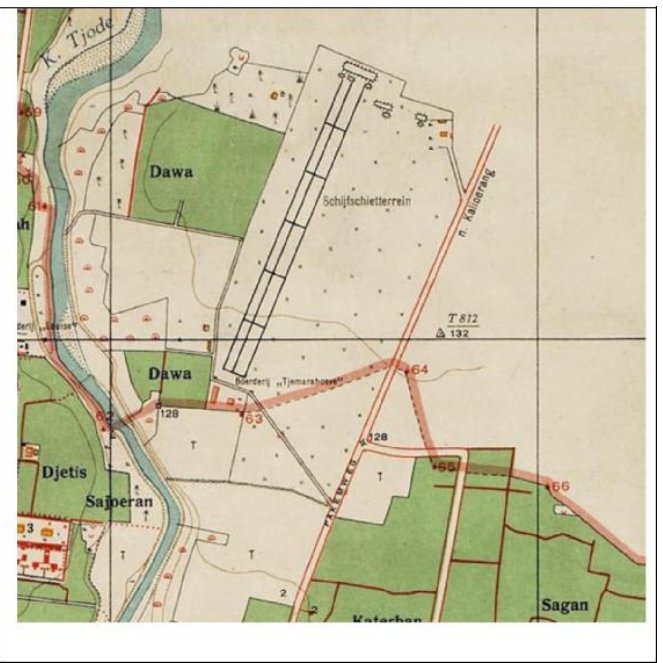

\subsection{Case 1: Urbanization of Jalan Kaliurang}

Jalan Kaliurang is a major road that links the boundary of Yogyakarta with Kaliurang - a resort area situated on the slope of Mount Merapi (Fig. 2) . It is not clear when did the road was first established but the Colonial Map of Yogyakarta published in 1925 shows that the road must have been existed since early twentieth century, under the name of Pakemweg. My auto- ethnographic observation shows a relatively fast change in the past 30 years especially after the 1990s. I have been observing this road as a daily commuter since the late 1980s, since I have to travel from my home in the northern part of Jalan Kaliurang (at $\mathrm{Km} .13$ ) towards the southern part of the road (at around $\mathrm{Km} .5$ ) to get to my office. In the 
late 80s the landscape of Jalan Kaliurang north of the Ring Road (refer to Fig. 3 - left) was predominantly rural. The changing of landscape around the campus seems to correspond to the growth of student's population within the campus. In 1993, there were only one building existed in the campus, hosting two faculties, i.e. Faculty of Civil Engineering and Planning, and Faculty of Industrial Technology. The population of students at the time was approximately 2000. Such number of population gradually triggered the boarding house businesses and supporting facilities by both local residents and private investors from outside the area.
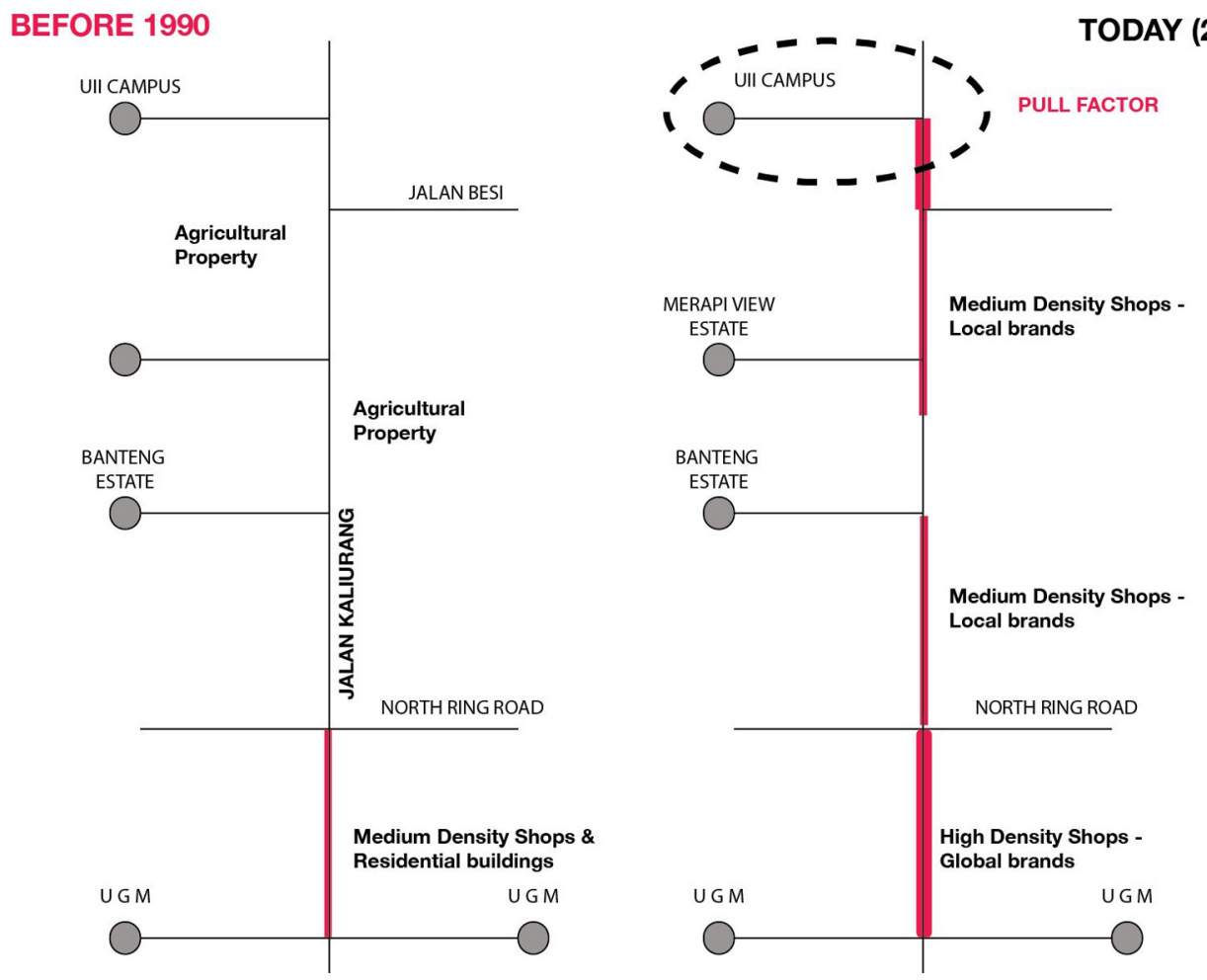

Fig. 3. The changing of urban densities on Jalan Kaliurang (1990 - 2018)

However, by 2018 the area occupied by UII main campus have reached 35 hectares, while the number of students occupying this campus have reached around 16,000. Observation suggests that these students are not only living around the campus. Many of them live near the city of Yogyakarta, thus they have to travel along Jalan Kaliurang to reach the main campus. The teaching and administrative staffs show the same mobility situation. The right map depicted in Fig. 3 suggests that the density of built environment along Jalan Kaliurang from the area of UGM (Universitas Gadjah Mada) Campus to UII main campus have changed significantly. I have not conducted a detailed mapping on building functions, but my frequent mobility along this road suggests that most of the buildings along Jalan Kaliurang are shops and eateries. The area between UGM and Ring Road has the highest density, occupied by high-end restaurants, shops, and luxury apartments. The density is lower in the northern side of Ring Road, but it is getting high again at around UII main campus. 
What occurs dominant along Jalan Kaliurang is the contestation between billboards and buildings, especially in the intersection where the traffic lights are located. The advertisement on billboards have in recent years characterized the urban scene of Yogyakarta. Tinarbuko's observation on the everyday practice of billboards placement suggest that these huge billboards are mostly illegal despite their permanent in appearance, because they violated the Municipal Regulation Number 2/2015, which prohibits anyone to place permanent advertisement on public garden and pedestrian ways [16].

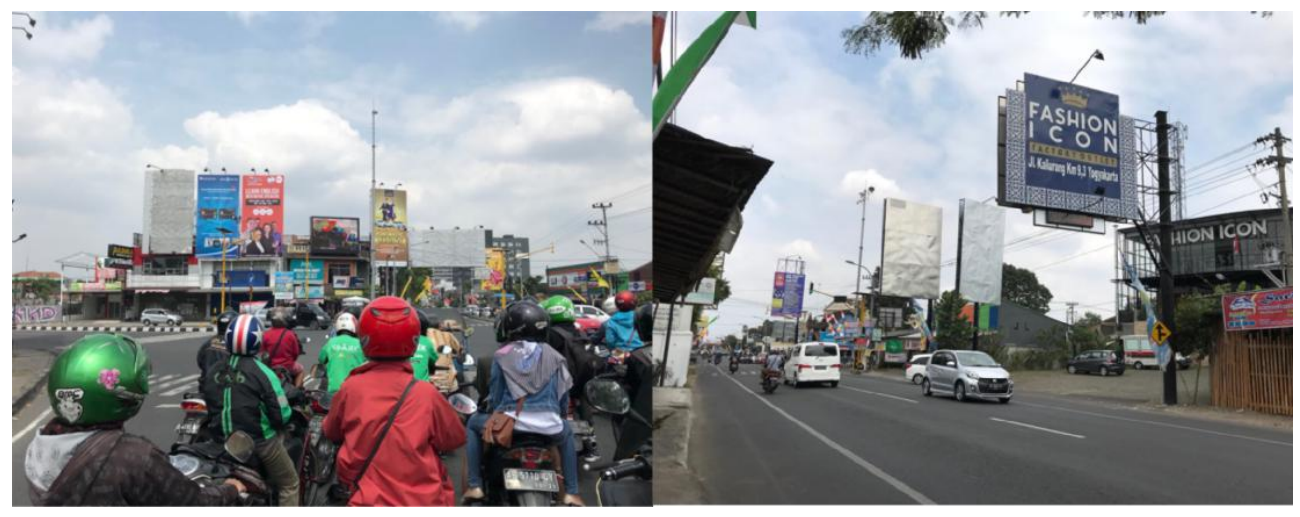

Fig. 4. [Left] Billboards on the intersection of Ring Road and Jalan Kaliurang; [Right] Billboards on the lower density of Jalan Kaliurang on the northern part (Km. 9.3)

\subsection{Case 2: Evolution of Kampung Code}

Kampung Code (pronounced "Cho-de") is perhaps the most legendary informal settlement in Indonesia because of its popularity, during the time when its dwellers dealt with the threat of eviction. The settlement is located on the corner of Gondolayu Bridge and Faridan M. Noto Street, on the bank of Code River (Fig. 5). The existence of this kampung can be traced back to early 1980s when the late Father Mangunwijaya - a priest cum architect advocated the dwellers against the threat of eviction by the municipal government. His strategy was to incorporate aesthetic approach in settlement consolidation - an action of turning a slum into the work of art. Such a strategy was proven successful as the local government did not execute the plan of eviction, yet a decade later (1992) the design of this settlement was granted the prestigious Aga Khan Award, which undoubtedly strengthen the existence this kampung against the possible threat of clearance. In other words, dwellers of Kampung Code have gained informal secure tenure.

The present (2018) condition of Kampung Code sees significant changes as a result of two major events, namely the extension of Gondolayu Bridge and the community's response to the 3M Concept (Mundur, Munggah, Madhep Kali - Back Away, Move Up, Face the River) of riverfront development introduced by the H.E. Sultan Hamengkubuwono $\mathrm{X}$ - the King and Governor of the Special Province of Yogyakarta. Renovation of Gondolayu Bridge was aimed at increasing the width of the bridge, to reduce the traffic congestion. This project had led to the demolition of some buildings in Kampung Code, because these buildings were located too close to the bridge. The second project that directly affect the landscape of Kampung Code was the implementation of 3M Concept. While implementation of $3 \mathrm{M}$ is not mandatory, it has been regarded by residents along the riverbank as a strong message from the Governor of Yogyakarta. Fig. 5 shows how brilliant residents of Kampung Code responded to the Governor's message. They need space for public gathering, thus the result of back away (mundur) arrangement is used to create an 
open space, which they use also for children playground. The passers by of Gondolayu Bridge can also witness the improvement of water quality of Code River.

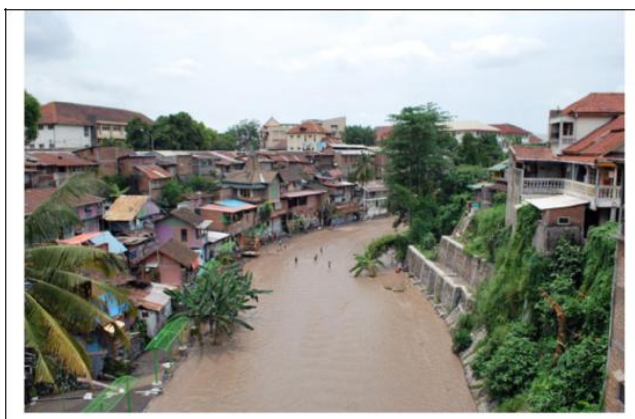

Fig. 5 [Top] Kampung Code during the Eruption of Mt. Merapi in 2010; [Left] The implication of $3 \mathrm{M}$ Concept on the build environment of Kampung Code.

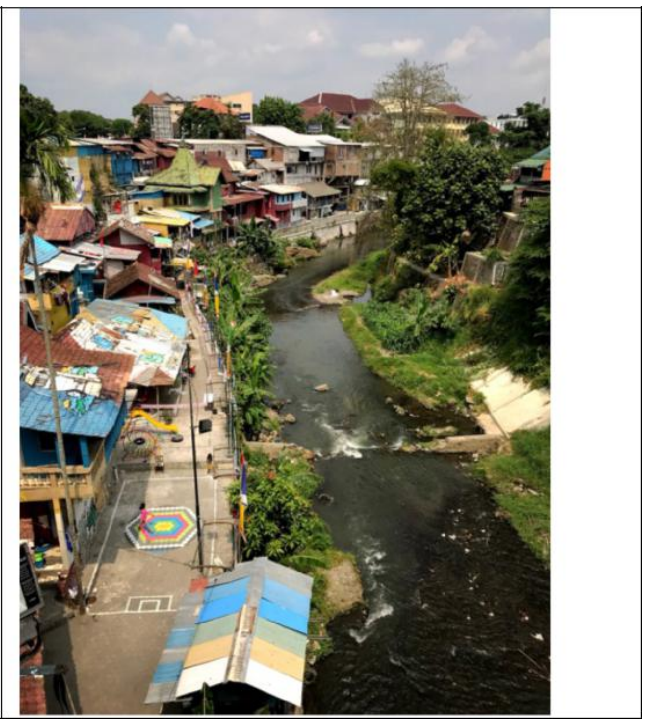

\section{Conclusion}

The two case studies presented in this paper reveal that urban character of Yogyakarta and vicinity show a result of people-driven urbanism (PDU). The first case study - urbanization of Jalan Kaliurang - shows seemingly formal built environments but there is an element of informality operates within them. The permanent huge billboards that advertise formal products are often located on the spot that violates local regulations regarding the placement of outdoor advertisements. The state's tolerance of such violation has caused the growing number of billboards in the public space - Tinarbuko called it sampah visual (visual rubbish) [17] - which in recent years have characterized the urban Yogyakarta. The existence of these billboards has certainly been driven by the need of business people to market their products. Similarly, in the second case study, the reason of existence of Kampung Code has been driven by the people's need of a more decent shelters. In the discourse of urban informality, informal settlement has been defined as urban assemblage that operates outside the formal control of the state [12]. However, both case studies presented in this paper show how state have played in making the informal approach to the production of built environment continues to operate in various forms of urban development. The acknowledgement of urban informality by the state as a valid approach for urban development marks a typical urban character of Yogyakarta in particular, and Indonesia in general.

\section{References}

1. P. Dongier, J.V. Domelen, E. Ostrom, A. Rizvi, W. Wakeman, A. Bebbington, S. Alkire, T. Esmail, and M. Polski, Community-Driven Development, retrieved from: http://siteresources.worldbank.org/INTPRS1/Resources/383606-1205334112622/ 5805_chap9.pdf (on 10 August 2018). 
2. Collins, English Dictionary, retrieved from: https://www.collinsdictionary.com/ dictionary/english/urbanism (on 9 August 2018)

3. The World Bank, Indonesia: Program Nasional Pemberdayaan Masyarakat Perdesaan (PNPM Pedesaan), retrieved from: http://www.worldbank.org/in/results/2009/01/21/ indonesia-program-for-communityempowerment-in-rural-areas-pnpm-rural (on 10 August 2018).

4. R. Yin, Case Study Research. Vol. 5 Applied Social Research Methods Series. London: Sage Publications (2003).

5. N.R. Cook and J.J. Ware, Ann. Rev. Public Health. 1983. 4:1-23

6. T.E. Adams, S.H. Jones and C. Ellis, Autoethnography: Understanding Qualitative Research, Oxford: Oxford University Press (2015).

7. J.F.C. Turner, Housing by People: Towards Autonomy in Building Environments, New York: Pantheon Books (1976).

8. K.S. Yap, Habitat International, 12 (2015)

9. H.D. Evers and R. Korff, Southeast Asian Urbanism, Singapore: Institute of Souteast Asian Studies (2000).

10. A. Roy and N. Alsayyad (Eds.), Urban Informality, Lanham: Lexington Books (2004).

11. M. Davis, Planet of Slums, London: Verso (2006).

12. K. Dovey and W. Raharjo, "Informal Urbanism in Yogyakarta" in K. Dovey, Becoming Places, London: Routledge (2010).

13. P. Guinness, Kampung, Islam, and State in Urban Java, Singapore: NUS Press (2009).

14. K. Dovey, Urban Design Thinking, London: Bloomsbury Academic (2016).

15. K. Kropf, Urban Design International, Vol. 1 No. 3 (1996).

16. M. Heidegger, Identity and Difference, New York: Harper and Row Publisher (1969).

17. S. Tinarbuko, Pajak Reklame dan Sampah Visual, in KR newspaper, 2 October 2017. 